Published by LPMP Imperium

Journal homepage: https:/ / ejournal.imperiuminstitute.org/ index.php/ BERDAYA

\title{
Peningkatan Penjualan M elalui Pengemasan, Labelling dan Branding Produk di D esa Sukaratu Kecamatan Cikeusal Kabupaten Serang
}

\author{
Dien Sefty Framita*, Dian Maulita \\ Akuntansi, Fakultas Ekonomi dan Bisnis, Universitas Serang Raya
}

\begin{abstract}
Packaging, labels, and brands are one of the main attractions for products to increase sales. Community Service A ctivities are carried out in Cikeusal Subdistrict, Serang Regency, with the target of being business actors producing chips in Sukaratu Village, Cikesal District, Serang R egency. Community Service A ctivities are carried out with the aim of providing an understanding of the emping-producing citizens regarding the importance of packaging, labeling and branding on a product that can increase sales levels and will automatically increase their economic income. The socialization was adjusted to the problems and needs faced by emping entrepreneurs in Cikeusal District.

The method of implementing the activity consists of three stages. The first stage of preparation includes presurvey, team formation and coordination of teams and participants as well as preparation of training tools and materials. The second stage is the program implementation stage in the form of socialization. Socialization is carried out through outreach (presentation of material) and discussion. The third stage is the evaluation and reporting stage. Evaluation is carried out by comparing the conditions of the participants before and after the program implementation with the interview and observation methods. A fter that, a report was prepared.
\end{abstract}

The material presented in the socialization was regarding the form of a legal entity and its important function of having a business license and business licensing mechanism. All stages of this activity have reached $100 \%$ implementation and have resulted in outcomes including understanding of community service participants about the importance of packaging, labeling and branding on a product.

\author{
Keywords \\ socialization, packaging, \\ labeling, and product \\ branding
}

\section{Article History}

Received 23 Nov 2020 / Accepted 20 Dec 2020 / First Published: 30 Dec 2020

\section{To cite this article}

Framita, D., \& Maulita, D. (2020). Peningkatan Penjualan Melalui Pengemasan, Labelling dan Branding Produk di Desa Sukaratu Kecamatan Cikeusal Kabupaten Serang. BERDAYA: Jurnal Pendidikan D an Pengabdian Kepada M asyarakat, 2(3), 107 - 118

DOI: $10.36407 /$ berdaya.v2i3.254

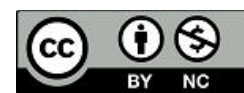

(C) 2020. This open access article is distributed under a CreativeCommons Attribution (CC-BY-NC) 4.0 license 
Kemasan, label, dan brand merupakan salah satu daya tarik produk guna meningkatkan penjualan. Kegiatan Pengabdiankepada Masyarakat dilaksanakan di Kecamatan Cikeusal Kabupaten Serang dengan target warga pelaku usaha penghasil emping di Desa Sukaratu Kecamatan Cikesal Kabupaten Serang.Kegiatan Pengabdiankepada Masyarakatdilaksanakan dengan tujuan memberi pemahaman para warga penghasil emping di mengenai pentingnya pengemasan, labelling,dan branding pada suatu produk dapat meningkatkan tingkat penjualan dan otomatis akan dapat meningkatkan pendapatan ekonominya.Sosialisasi tersebut disesuaikan dengan permasalahan dan kebutuhan yang dihadapi oleh pelaku usaha emping di Kecamatan Cikeusal.

Metode pelaksanaan kegiatan terdiri dari tiga tahap. Pertama tahap persiapan meliputi pra survei, pembentukan timdankoordinasi tim dan peserta serta persiapan alat dan bahan pelatihan. Tahap kedua yaitu tahap pelaksanaan program berupa sosialisasi. Sosialisasi dilakukan melalui penyuluhan (pemaparan materi) dan diskusi. Tahap ketiga yaitu tahap evaluasi dan pelaporan. Evaluasi dilakukan dengan membandingkan kondisi peserta sebelum dan sesudah pelaksanaan program dengan metode wawancara dan observasi. Setelah itu, dilakukan penyusunan Iaporan.

Materi yang disampaikan dalam sosialisasi mengenai bentuk badan hukum dan fungsi pentingnya memiliki izin usaha serta mekanisme perizinan usaha. Seluruh tahapan kegiatan ini telah mencapai $100 \%$ pelaksanaan dan telah menghasilkan luaran diantaranya pemahaman peserta kegiatan pengabdian mengenai pentingnya pengemasan, labelling,dan branding pada suatu produk

Reviewing Editor

Kata Kunci : Sosialisasi, Pengemasan, Labelling, dan Suryani, IAIN Lhokseumawe, Aceh Branding produk

\section{PENDAHULUAN}

Salah satu wujud dari Usaha Mikro Kecil Menengah (UMKM) yang menjadi soko guru perekonomian selain dari koperasi adalah home industri atau industri rumah tangga. Adanya krisis global pada tahun 2008 merupakan bukti nyata bahwa sebagian besar UMKM khususnya industri rumah tangga sedikit bahkan tidak sama sekali terkena dampak dari krisis tersebut. Hal inilah yang menyebabkan peningkatan jumlah industri rumaha tangga setiap tahunnya. Namun bertambahnya jumlah industri rumah tangga tidak dibarengi dengan meningkatnya kualitas terutama dalam hal strategi branding (labeling dan packaging) dan teknis-teknis marketing. Hal ini tak lepas dari ketidakmaksimalan pelaku UMKM untuk memperhatikan branding maupun teknis-teknis marketing produk yang dihasilkan tersebut. Packaging, Labeling dan 
Brandingmerupakan identitas yang secara langsung menjadi penampilan produk tersebut sehingga pengel olaan penampilan menjadi sal ah satu aspek utama yang harus diperhatikan oleh pelaku industri rumah tangga, karena lima detik pandangan pertama sangat menentukan pilihan para konsumen di pasaran (Irrubai, 2015).

Ketatnya persaingan bisnis dalam UMKM menuntut para pelaku UMKM untuk lebih inovatif dalam memasarkan produknya sal ah satunya dengan memberikan sentuhan yang berbeda dan unik dalam pembuatan kemasan produk yang dihasilkan.Kemasan ini di gunakan dalam berbagai macam komuditas baik komuditas pangan maupun non pangan. Manfaat pengemasan atau packaging yang baik yaitu melindungi produk dari bahaya yang timbul pada saat pendistribusian, penyimpanan dan menyediakan produk yang praktis serta mudah di bawa oleh konsumen. Untuk komuditas pangan kemasan merupakan faktor penting dalam keamanan produk karena kemasan akan melindungi pangan dari kerusakan fisik, membuat produk tetap utuh sampai ketangan konsumen serta menghindari dari kontaminasi bahan kimia dan mikrobi olog (Herudiansyah, Candera, \& Pahlevi, 2019).

Selain kemasan hal lain yang tidak kalah penting untuk menarik minat pembeli adalah Label produk yang merupakan identitas dari sebuah produk yang akan di pasarkan.Dengan adanya label produk pada kemasan produk menjadi penguat branding serta mempermudah konsumen dalam memilih produk yang akan di belinya. Dalam label yang terdapat dalam kemasan produk menyajikan informasi berupa brand, komposisi, legalitas, fungsi dan petunjuk produk (Herudiansyah, Candera, \& Pahlevi, 2019).

Di akhir tahun 1980-an muncul pemikiran untuk menjadikan brand sebagai sebuah asset yang memiliki ekuitas yang menjadi penggerak strategi dan kinerja bisnis. Ide pemikiran ini berpengaruh dalam menimbulkan arus perubahan yang dramatis dalam persepsi pemasaran dan manajemen brand, mulai dari perubahan cara pengukuran dan pengelolaan brand, serta peran para eksekutif pemasaran (David, 2015). Cara pandang yang menjadikan brand sebagai sebuah asset diadopsi oleh beberapa perusahaan dan perusahaan yang berhasil mengimplementasikan pandangan tersebut dapat menilai bahwa brand building beralih dari upaya taktis yang dapat didelegasikan dengan aman melalui satu tim komunikasi menjadi sebuah strategi penggerak bisnis(Nastain, 2017).

\section{Sasaran Kegiatan}

Rencana pengabdian kepada masyarakat yang akan Tim kami laksanakan berlokasi di Kecamatan Kramatwatu Kabupaten Serang. Desa Sukaratu merupakan salah satu dari 15 desa yang berada di wilayah administratif Kecamatan Cikeusal Kabupaten Serang dan terletak di sebelah barat daya kota Serang dengan 12 desa/ kelurahan.Secara demografis, Desa Sukaratu Sebelah Utaraberbatasan dengan Desa Sukamaju, Sebelah Selatanberbatasan denganDesa Cirangkong Kecamatan Petir, Sebelah Timur berbatasan denganDesa Cikeusal,Sebelah Baratberbatasan denganDesa Sukaraja.

Sebagian besar penduduk Desa Sukaratu bekerja di sektor Perdagangan dan Pertanian, Hal ini didukung oleh faktor jenis usaha warungan atau kelontongan mendominasi di tiap-tiap kampung, juga di bidang Pertanian dimana lahan garap pesawahan yang produktif yang tersedia luas serta adanya Gabungan kelompok tani yang kegiatannya berjalan dengan baik juga mewarnai kegiatan usaha di Desa Sukaratu. Terdapat juga lahan produktif berupa kebun tangkil. 
Hampir di setiap halaman rumah warga juga terdapat pohon tangkil yang menjadi bahan dasar dalam pembuatan emping.

Banyak warga Desa Sukaratu sudah lama menjadi peghasil emping kegiatan usaha rumahan ini sudah turun temurun sejak dulu tetapi karena keterbatasan pemikiran dan keterbatasan para warga penghasil emping ini dalam mengetahui pentingnya pengemasan, labelling, branding pada suatu produk dapat meningkatkan tingkat penjualan dan otomatis akan dapat meningkatkan pendapatan ekonominya.

\section{Masalah yang ingin dipecahkan}

Berdasarkan analisa situasi yang telah dipaparkan, dapat disimpulkan beberapa permasalahan yang dihadapipara warga pelaku usaha penghasil emping di Desa Sukaratu Kecamatan Cikesal Kabupaten Serang adalahbelum adanya pemahaman para warga penghasil emping ini mengenai pentingnya pengemasan, labelling,dan branding pada suatu produk dapat meningkatkan tingkat penjualan dan otomatis akan dapat meningkatkan pendapatan ekonominya.

Motivasi yang mendasari pengabdian ini adalah ingin memberikan dan meningkatkan pemahaman kepada para warga penghasil emping ini mengenai pentingnya pengemasan, labelling,dan branding pada suatu produk dapat meningkatkan tingkat penjualan dan otomatis akan dapat meningkatkan pendapatan ekonominya. Solusi dari program Pengabdian kepada masyarakat disesuaikan dengan permasalahan yang dihadapi oleh pelaku usaha. Adapun solusi tersebut meliputi :

Tabel 1.

Permasalahan dan Solusi Bagi Pelaku U saha

\begin{tabular}{llll}
\hline \multicolumn{1}{c}{ Permasalahan } & \multicolumn{1}{c}{ Solusi } \\
\hline $\begin{array}{l}\text { Belum adanya pemahaman pelaku usaha } \\
\text { emping di Desa Sukaratu Kecamatan Cikesal } \\
\text { Kabupaten Serang mengenai Pengemasan } \\
\text { produk }\end{array}$ & $\begin{array}{l}\text { Sosialisasi pengenalan mengenai } \\
\text { pengemasan produk }\end{array}$ & \\
\hline $\begin{array}{l}\text { Belum adanya pemahaman pelaku usaha } \\
\text { emping di Desa Sukaratu Kecamatan Cikesal }\end{array}$ & $\bullet$ & $\begin{array}{l}\text { Sosialisasi pengenalan mengenai } \\
\text { fungsi penting dari labelling produk }\end{array}$ \\
Kabupaten Serang mengenai Labelling produk & & \\
\hline $\begin{array}{l}\text { Pelaku usaha emping di Desa Sukaratu } \\
\text { Kecamatan Cikesal Kabupaten Serang } \\
\text { mengenai branding produk }\end{array}$ & $\bullet$ & Sosialisasi branding produk \\
\hline
\end{tabular}

Melalui kegiatan-kegiatan yang paparkan diharapkan mampu memberikan masa manfaat yang terus-menerus dapat diterima oleh pelaku usaha yang sangat minim pengetahuan dan pemahaman mengenai pengemasan, labelling, dan branding. Sehingga masalah-masalah yang dihadapi pelaku usaha tersebut yang terkait dengan pengetahuan mengenai pengemasan, labelling, dan branding dapat segera teratasi dan terbantukan. Tahapan lainnya yang terpenting untuk memantau per kegiatan yang dirancang adalah evaluasi atas perkembangan usaha. 


\section{MATERI DAN METODE}

\section{Materi}

Tahapan kegiatan program Pengabdian Kepada Masyarakat dapat dilihat pada tabel berikut :

Tabel 2.

Tahapan kegiatan program Pengabdian K epada M asyarakat

\begin{tabular}{|l|l|}
\hline \multicolumn{2}{|c|}{ Tahapan Persiapan } \\
\hline Pra survei & Mengenali masalah yang dihadapi oleh peserta \\
\hline Penyusunan Tim PKM & Penyusunan Tim untuk menyelesai kan permasalahan peserta \\
\hline Persiapan Bahan Pelatihan & Mempersiapkan alat serta membuat materi sosial isasi \\
\hline \multicolumn{1}{|c|}{ Tahap Real isasi kegiatan sosialisasi (Dilaksanakan di daerah asal peserta) } \\
\hline Materi Pertama & Pengemasan produk \\
\hline Materi Kedua & Labelling produk \\
\hline Materi Ketiga & Branding produk \\
\hline \multicolumn{2}{|c|}{ Evaluasi Program } \\
\hline $\begin{array}{l}\text { Penilaian sosialisasi ini } \\
\text { sebelum program PkMah dengan cara membandingkan tingkat pemahaman peserta } \\
\text { sosialisasi dilaksanakan }\end{array}$ \\
\hline \multicolumn{2}{|c|}{ sosialisasi dilaksanakan dan tingkat pemahaman peserta setelah } \\
\hline $\begin{array}{l}\text { Pertanggungjawaban kegiatan pengabdian yaitu dilakukan dengan menyusun laporan kegiatan } \\
\text { yang kemudian output akhirnya adalah publikasi dalam jurnal nasional. }\end{array}$ \\
\hline
\end{tabular}

Adapun tahapan dalam melaksanakan solusi yang ditawarkan untuk mengatasi permasalahan pelaku usaha dapat dilihat berdasarkan kerangka pemecahan masalah sebagai berikut :

\begin{tabular}{|l|l|l|}
$\begin{array}{l}\text { Permasalahan : } \\
\text { Beberapa pelaku } \\
\text { usaha belum } \\
\text { memiliki } \\
\text { pengetahuan dan } \\
\text { motivasi yang } \\
\text { cukup tentang } \\
\text { pengemasan, } \\
\text { labellingdan } \\
\text { branding produk }\end{array}$ & $\begin{array}{l}\text { Solusi : } \\
\text { Sosialisasi } \\
\text { pengetahuan } \\
\text { mengenai } \\
\text { pengemasan, } \\
\text { labellingdan branding } \\
\text { produk }\end{array}$ \\
\hline
\end{tabular}

\section{G ambar 1.}

Tahapan Pelaksanaan Solusi Permasalahan Pelaku U saha

\section{Peserta}

Peserta Pengabdian Kepada Masyarakat yang merupakan pelaku usaha emping, pemuda pemudi setempat, perwakilan perangkat desa dan tokoh msyarakat di Desa Sukaratu Kecamatan Cikesal Kabupaten Serang terdiri dari ibu-ibu pelaku usaha dalam lingkup Desa Sukaratu Kecamatan Cikesal yang menjadi penghasil emping. Partisipasi peserta dalam mengikuti sosialisasi pada kegiatan Pengabdian Kepada Masyarakat adalah : 
1. Peserta pelaku usaha emping menyediakan tempat untuk penyelenggaraan kegiatan sosialisasi yaitu bertempat di aula Kantor Desa Sukaratu Kecamatan Cikesal

2. Ibu-ibu pelaku usaha berperan sebagai peserta sosialisasi dan aktif berperan dalam kegiatan diskusi / tanyajawab

\section{Prosedur dan M etode}

Ada beberapa metode pendekatan yang digunakan dalam pelaksanaan program, meliputi :

Sosialisasi- Kegiatan pengabdian kepada masyarakat dilaksanakan dalam bentuk sosialisasi kepada peserta pengusaha penghasil emping di Desa Sukartu Kecamatan Cikesal Kabupaten Serang. Sosialisasi tersebut dilakukan dengan penyampaian substansi bahan materi kepada peserta mengenai pengemasan, labelling, dan branding produk. Materi yang akan disampaikan diharapkan dapat memberikan peningkatan pengetahuan dan pemahaman untuk selanjutnya dapat diterapkan oleh peserta dalam mengembangkan usahanya. Adapun materi yang akan disampaikan pada peserta meliputi :

Tabel 3.

Materi Kegiatan Pengabdian Kepada Masyarakat

\begin{tabular}{cll}
\hline No & \multicolumn{1}{c}{ Pemateri } & \multicolumn{1}{c}{ Materi Sosialisasi } \\
\hline 1 & Dien Sefty Framita, SE., M.Akt & Pengemasan produk \\
2 & Dian Maulita, SE., MM. & Labelling dan Branding produk \\
\hline
\end{tabular}

Tanya Jawab- Selesai penyampaian materi dilanjutkan dengan tanya jawab antara pemateri dengan peserta. Tanya jawab dilakukan agar peserta mendapatkan solusi dari permasalahan yang dihadapi peserta dan peserta pun mengerti materi yang telah disampaikan. Melalui tanya jawab juga peserta dapat berbagi pengalaman terkait dengan permasalahan yang sedang dihadapi peserta lainnya.

\section{HASIL DAN PEMBAHASAN}

\section{Pelaksanaan Kegiatan}

Kegiatan Pengabdian Kepada Masyarakat dalam bentuk sosialisasi kewirausahaan dan perizinan usaha telah dilaksanakan oleh Tim Pengabdian Kepada Masyarakat pada hari Jum'at, 10januari 2020 di Desa Sukaratu Kecamatan Cikesal Kabupaten Serang. Kegiatan dihadiri oleh 5 ibu-ibu pengusaha emping, pemuda pemudi, perwakilan perangkat dan tokoh masyarakat. Adapun roundown acara kegiatan sosialisasi terdapat pada tabel berikut:

Tabel 4.

Roundown A cara Pengabdian Kepada M asyarakat

\begin{tabular}{|c|l|l|}
\hline Durasi & \multicolumn{1}{|c|}{ Uraian } & \multicolumn{1}{c|}{ Pelaksana } \\
\hline $07.30-08.00$ & Persiapan awal & Tim PKM dan peserta \\
\hline $08.00-08.15$ & Pembukaan acara & Dien Sefty Framita, M.Akt. \\
\hline $08.15-08.30$ & Sambutan & Perangkat Desa \\
\hline $08.30-08.45$ & Wawancara dan Observasi & Tim PKM \\
\hline $08.45-09.15$ & Materi Pengemasan produk & Dien Sefty Framita, SE., M.Akt. \\
\hline $09.15-09.45$ & Materi Labelling produk & Dian Maulita, SE., MM. \\
\hline $09.45-10.15$ & Materi branding produk & Dian Maulita, SE., MM. \\
\hline $10.15-10.45$ & Wawancara dan observasi serta & Tim PKM \\
\hline
\end{tabular}


Dien Sefty Framita, Dian M aulita

socialization, packaging, labeling, and product branding

\begin{tabular}{|l|l|l|}
\hline & pembagian doorprise & \\
\hline $10.45-1100$ & Penutup & Tim PKM \\
\hline $11.00-1115$ & Foto bersama & Tim PKM dan peserta \\
\hline
\end{tabular}

Pada setiap rangkaian acara pada kegiatan sosialisasi dari awal hingga akhir acara diikuti peserta dengan sangat antusias, apalagi pada saat sesi tanya jawab. Tanya jawab berlangsung panjang melebihi dari rencana pada roundown acara karena tingginya keingintahuan secara detail dari peserta terkait mencari solusi dari permasalahan yang mereka hadapi dan seputar sharing pengalaman antara peserta satu dengan ynag lain dan juga dengan pemateri.

Hasil pada pemaparan materi pertama mengenai Pengemasan Produk yang disampaikan oleh Dien Sefty Framita, M .Akt. dijelaskan sebagai berikut :

William J. Staton (Sunyoto, 2013) mendefinisikan Packaging may be defined as all the activities of designing and producing the container or wrapper for a product yang artinya kemasan adalahsebuah kegiatan merancang dan memproduksi bungkusan atau kemasan suatu produk.Kemudian, Kemasan dalam (Kamus Besar Bahasa Indonesia, 2016, hal. 537)berarti hasil mengemas/ bungkus pelindung barang dagangan.

Desain kemasan selain untuk memberikan daya tarik dari sisi visual tentunya desain kemasan harus menjadi media komunikasi antar produsen dengan cal on konsumen, sehingga dalam desain kemasan harus tercantum informasi-informasi yang harus diketahui oleh calon konsumen sehingga cal on konsumen merasa tidak asing dengan produk yang dikemas(M ukhtar \& N urif, 2015).

Direktorat Jenderal Pengelolahan dan Pemasaran Hasil Pertanian Kementrian Pertanian Republik Indonesia (2012) menginformasikan secara umum fungsi kemasan adalah: 1) Melindungi dan mengawetkan produk, 2) Sebagai identitas produk, 3) Meningkatkan efisiensi.

1. Pada tahap awal dilakukan wawancara dan observasi kepada peserta mengenai pemahaman Pengemasan Produk. Hasilnya hanya 50\%seluruh peserta yang paham bagaimana pentingnya tampilan pengemasan produk dapat berperan dalam meningkatkan nilai jual produk.

2. Pada saat pemaparan materi disampaikan, supaya peserta mulai paham bagaimana suatu pengemasan produk dibuat semenarik mungkin dengan tujuan menarik perhatian konsumen untuk membeli produk kita. Dengan menggunakan kemasan dengan kualitas baik pun akan menjaga daya tahan produk supaya tidak mudah rusak.

3. Setelah materi disampaikan, peserta antusias menyampaikan berbagai pertanyaan seputar pengemasan produk. Dalam pertemuan ini, kami membuka mindset kepada peserta bagaimana manfaat dan pentingnya kemasan untuk sebuah produk. Kemasan yang menarik dari bentuk atau warna dapat menarik perhatian konsumen untuk membeli produk dan dapat membuat konsumen mudah ingat terhadap produk yang kita pasarkan. Semakin mudah ingat dan tertarik knsumen terhadap produk yang kita psarkan maka akan berpengaruh semakin meningkatnya pendapatan masyarakat.

4. Pada wawancara dan observasi akhir, menunjukkan perubahan dan peningkatan yaitu hasilnya $100 \%$ seluruh peserta paham bagaimana lebih meningkatkan kemampuan berinovasidalam pengemasan produk yang dipasarkan supaya menjadi menarik, sehingga tujuan untuk dapat menarik perhatian pembeli dapat tercapai. Serta tentunya dapat berdampak positif dapat meningkatkan hasil pendapatan masyarakat. 


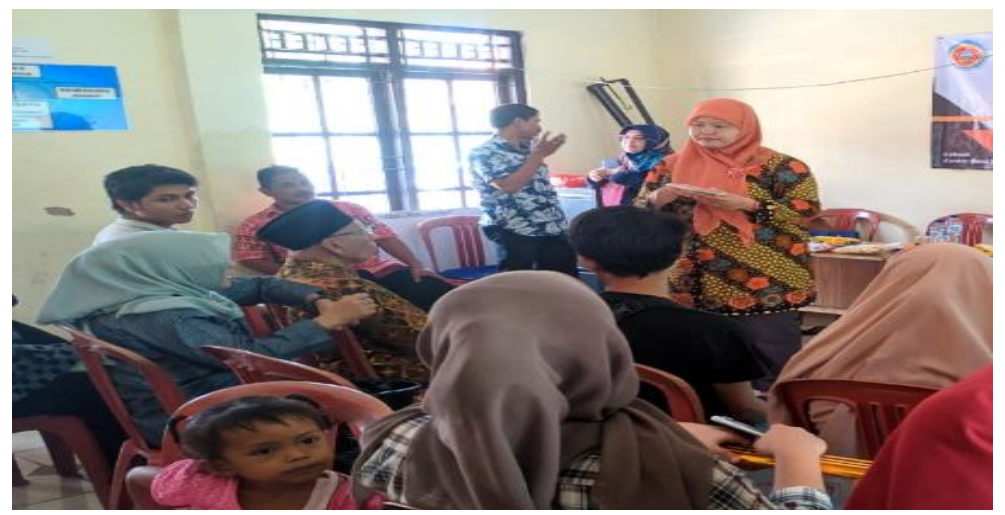

Gambar 2.

Foto Pemaparan M ateri

Pengemasan Produk

\section{Hasil pada pemaparan materi kedua mengenai Labelling produk yang disampaikan oleh Dian Maulita, SE., M M . dijelaskan sebagai berikut :}

Menurut (Marinus, 2002) label ialah sesuatu bagian dari suatu produk yang bawa data verbal tentang produk ataupun penjual nya.

Fungsi serta Tujuan Label

Label bukan cuma bagaikan perlengkapan penyampai data, tetapi pula berperan bagaikan iklan serta branding suatu produk. Menurut(Kotler, 2009), fungsi label merupakan bagaikan berikut:

- Label mengenali produk ataupun merk.

- Label memastikan kelas produk.

- Label menggambarkan sebagian perihal menimpa produk (siapa pembuatnya, dimana terbuat, kapan terbuat, apa isinya, gimana memakainya, serta gimana memakai secara nyaman).

- Label mempromosikan produk melalui aneka foto yang menarik.

Ada pula tujuan label merupakan bagaikan berikut:

- Berikan data tentang isi produk yang diberi label tanpa wajib membuka kemasan.

- Berperan bagaikan fasilitas komunikasi produsen kepada konsumen tentang hal- hal yang butuh dikenal oleh konsumen tentang produk tersebut, paling utama hal- hal yang kasat mata ataupun tidak dikenal secara raga.

- Berikan petunjuk yang pas pada konsumen sampai diperoleh guna produk yang optimum.

- Fasilitas periklanan untuk produsen.

- Berikan rasa nyaman untuk konsumen.

Berdasarkan wawancara dan observasi sebelum materi disampaikan, hampir seluruh peserta tidak paham begitu pentingnya labelling pada produk yang mereka jual. Mereka menganggap labellinghanya menjadi usaha yang membang-buang modal dan tidak berpengaruh terhadap perkembangan usaha penjualan masyarakat.

Pada saat pemaparan materi disampaikan mengenai pentingnyalabelling produk. Bagaimana dengan labelling produk akan meningkatkan kepercayaan dan ketertarikan konsumen terhadap produk yag mereka pasarkan. Dengan mencantumkan nama produk, gambar, komposisi bahan, tanggal expired, kehalalan, dsb maka akan menimbulkan kepercayaan pembeli akan kualitas dan rasa yang terjamin dan menghilangkan keragu-raguan atas ketakutan mereka akan dampak 
negative dari mengonsumsi produk yang mereka pasarkan. Merekomendasikan kepada masyarakat juga dimana dapat membuat label produk yang menarik dengan harga yag terjangkau.

Pada saat setelah materi disampaikan, diadakan diskusi terkait dengan banyaknya pertanyaan yang muncul mengenai apa saja isi dari label pada produk, manfaat adanya label produk, dan berinovasi dalam membuat desainnya semenarik mungkin.

Pada wawancara dan observasi akhir, menunjukkan perubahan dan peningkatan yaitu peserta PKM menjadi paham mengenai bentuk label pada produk dan pentingnyalabelling produk. $100 \%$ dari peserta yang antusias tergerak ingin segera mendesain label pada produknya.

\section{Hasil pada pemaparan materi ketiga mengenai branding produk, yang disampaikan oleh Dian Maulita, SE., M M . dijelaskan sebagai berikut :}

Menurut Bruce J.Walker dalam (Sunyoto, 2013)mengatakan bahwa merek adalah suatu nama, istilah, tanda atau desain atau gabungansemua yang diharapkan mengidentifikasikan barang atau jasa dari seseorang atau sekel ompok penjual.

Merek yang kuat sangat berharga di dalam pertempuran untuk mendapatkan pelanggan dan sangatlah berharga untuk kita meluangkan waktu untuk berinvestasi diriset, definisi serta membangun merek kita. Merek adalah kombinasi dari atributatribut, dikomunikasikan melalui nama atau simbol, yang dapat mempengaruhi proses pemilihan suatu produk atau layanan di benak konsumen (Rufaidah, 2015).Merek mempengaruhi persepsi konsumen terhadap produk yang akan dibeli maka persaingan antar perusahaan adalah persaingan persepsi bukan produk (Tjiptono, 2015).

Merek mempunyai enam tingkat pengertian, yaitu (Rangkuti, 2012): a. Atribut Atribut produk menjadi perhatian yang pertama bagi pembeli karena atribut inilah yang mencerminkan produk. b. Manfaat Pembeli memilih produk karena produk tersebut memberikan manfaat kepada pemakainya. Dengan demikian atribut itu sendiri harus diterjemahkan ke dalam manfaat yang fungsional dan emosional. c. Nilai M erek juga menyatakan sesuatu tentang nilai produk. Pembeli memberi nilai tersendiri terhadap produk dengan merek tertentu. Pembeli juga menilai paket manfaat yang ditawarkan oleh merek produk.

Semua proses yang dilakukan untuk membangun sebuah brand tidak bisa dilakukan dalam waktu yang sebentar. Sebabnya sederhana, karena proses penerjemahan dan deliver value itu tidak bisa sebentar. Konsistensi itu yang butuh pembuktian di lapangan. Jika sebuah brand sudah terbukti bisa mendeliver value-nya dengan konsisten, baru proses branding itu dianggap berhasil. Dalam kondisi keuangan yang terbatas, konsultan UMKM perlu menemukan solusi yang kreatif misalnya dengan memanfaatkan womm (word of mouth marketing) dan socmed (social media), dan kegiatan-kegiatan pendampingan secara optimal agar UMKM di Bandung Jawa Barat mampu membuat branding produknya dengan baik (Stephen, 2016).

1. Berdasarkan wawancara dan observasi awal menunjukkan bahwa separuh jumlah peserta sudah mengetahui pentingnya brandinguntuk produk mereka.

2. Pada saat pemaparan materi disampaikan mengenai pentingnya branding dan dampak besar terhadap meningkatnya penjualan. Dengan memiliki branding produk yang menarik akan membuat konsumen mudah ingat akan produk yag dipasarkan. Semakin mudah konsumen itu mengingat branding produk kita maka akan menjadi salah satu factor mudahnya branding produk kita tersebar luas kepada konsumen lain yang belum pernah 
membeli produk kita dengan harapan dengan mendengar dari konsumen lain dapat memunculkan ketertarikan mereka untuk membeli produk yang dipasarkan.

3. Pada saat selesai pemaparan materi, peserta langsung bersemangat mengajukan pertanyaan bahkan saling berdiskusi menyampaikan ide mereka mengenai nama branding produk apa yang akan mereka pakai untuk sebagai merek jual bagi produk mereka.

4. Pada wawancara dan observasi akhir, menunjukkan perubahan dan peningkatan yaitu $100 \%$ peserta memahami dampak positif dengan menggunakan branding untuk memasarkan produk mereka kepada konsumen.

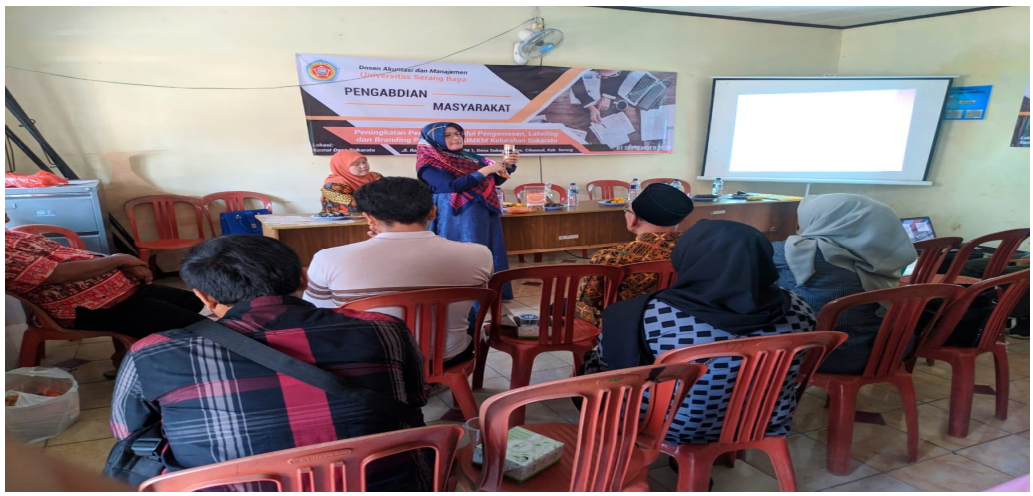

Gambar 3.

Foto Pemaparan Materi M engenai Labeling dan Branding Produk

Kegiatan program Pengabdian Kepada Masyarakatyang telah dilaksanakan menghasilkan luaran sebagai berikut:

\section{Tabel 5.}

Luaran P rogram P elaksanaan Pengabdian

\begin{tabular}{|l|c|c|c|c|}
\hline \multicolumn{1}{|c|}{ Sosialisasi } & \multicolumn{1}{|c|}{ Hasil } & $\begin{array}{c}\text { Prosentasi pra } \\
\text { materi }\end{array}$ & $\begin{array}{c}\text { Prosentasi } \\
\text { pasca materi }\end{array}$ & Keterangan \\
\hline $\begin{array}{l}\text { Pengemasan } \\
\text { produk }\end{array}$ & $\begin{array}{l}\text { Memahami pentingnya } \\
\text { pengemasan produk }\end{array}$ & $50 \%$ & $100 \%$ & Peningkatan \\
\hline $\begin{array}{l}\text { Labelling } \\
\text { produk }\end{array}$ & $\begin{array}{l}\text { Memahami bentuk dan } \\
\text { pentingnya labelling } \\
\text { produk }\end{array}$ & $10 \%$ & $100 \%$ & Peningkatan \\
\hline $\begin{array}{l}\text { Branding } \\
\text { produk }\end{array}$ & $\begin{array}{l}\text { Memahamibranding } \\
\text { produk }\end{array}$ & $50 \%$ & $100 \%$ & Peningkatan \\
\hline
\end{tabular}

\section{Evaluasi Kegiatan}

Evaluasi program kegiatan pengabdian kepada masyarakat dilakukan untuk mengetahui hasil dan kemajuan dari pelaksanaan kegiatan pengabdian kepada masyarakatpengabdian kepada masyarakat. Evaluasi program ini adalah dengan cara membandingkan tingkat pemahaman peserta sebelum sosialisasi dilaksanakan dan tingkat pemahaman peserta setelah kegiatan pengabdian masyarakat berupa sosialisasi atau penyuluhan dilaksanakan. Secara rinci, evaluasi program dapat dilihat berdasarkan tabel berikut: 
Dien Sefty Framita, Dian M aulita

socialization, packaging, labeling, and product branding

\section{Tabel 6.}

Evaluasi Program Kegiatan

\begin{tabular}{ccll}
\hline No & Program & \multicolumn{1}{c}{ Indikator } & \multicolumn{1}{c}{ Instrumen } \\
\hline 1 & Pengemasan produk & $\begin{array}{l}\text { Pemahaman peserta PKM mengenai } \\
\text { Pengemasan produk. }\end{array}$ & $\begin{array}{l}\text { Observasi dan } \\
\text { wawancara }\end{array}$ \\
2 & Labelling produk & $\begin{array}{l}\text { Pemahaman pesertapengabdian } \\
\text { kepada masyarakat mengenai }\end{array}$ & $\begin{array}{l}\text { Observasi dan } \\
\text { pengetahuan mengenai Labelling } \\
\text { produk. }\end{array}$ \\
& Branding produk & $\begin{array}{l}\text { Pemahaman pesertapengabdian } \\
\text { kepada masyarakat mengenai } \\
\text { Branding produk. }\end{array}$ & Observasi dan \\
& &
\end{tabular}

\section{KESIMPULAN}

\section{Kesimpulan}

Kegiatan sosialisasi yang telah dilaksanakan oleh Tim Pengabdian Kepada Masyarakat di Kecamatan Kramat Watu Kabupaten Serang menghasilkan kesimpulan yaitu:

Pertama, pelaksanaan sosialisasi kewirausahaan telah memenuhi hasil luaran yang ditargetkan, yaitu terjadi peningkatan pemahaman mengenai pengemasan produk dari $50 \%$ menjadi $100 \%$. seluruh peserta paham bagaimana lebih meningkatkan kemampuan berinovasidalam pengemasan produk yang dipasarkan supaya menjadi menarik, sehingga tujuan untuk dapat menarik perhatian pembeli dapat tercapai. Serta tentunya dapat berdampak positif dapat meningkatkan hasil pendapatan masyarakat

Kedua, kegiatan sosialisasi mengenai labelling produktelah memenuhi hasil luaran yang ditargetkan, yaitu terjadi peningkatan pemahaman dari $10 \%$ menjadi $100 \% 100 \%$ dari peserta yang antusiasmemiliki keinginan untuk membuat label pada produk mereka dengan indicator banyaknya pertanyaan yang muncul mengenai apa saja isi dai label pada produk, manfaat adanya label produk, dan berinovasi dalam membuat desainnya semenarik mungkin.

Terakhir, kegiatan sosialisasi mengenai branding produktelah memenuhi hasil luaran yang ditargetkan, yaitu terjadi peningkatan pemahaman dari $50 \%$ menjadi $100 \% .100 \%$ peserta memahami dampak positif dengan menggunakan branding untuk memasarkan produk mereka kepadakonsumen.

\section{Saran kegiatan Lanjutan}

Diperlukan pelatiahan lebih lanjut tentang cara mendisain kemasan, labeling dan branding bagi UMKM sehingga pelaku UKM dapat mendisain sendiri merek, label dan kemasan produknya sehingga dapat meminimalisir biaya produksi. 


\section{REFERENSI}

David, A. (2015). Aaker on Branding 20 Prinsip Esensial : M engelola dan M engembangkan Brand. Jakarta: Gramedia Pustaka Utama.

Herudiansyah, G., Candera, M., \& Pahlevi, R. (2019). Penyuluhan Pentingnya Label Pada Kemasan Produk dan Pajak Pada Usaha Kecil Menengah (UKM) Desa Tebedak II Kecamatan Payaraman Ogan Ilir. Jurnal Imiah Pengabdian Kepada M asyarakat, 1(2) 84-89.

Irrubai, M. L. (2015). Strategi Labeling, Packaging dan Marketing Produk Hasil Industri Rumah Tangga Di Kelurahan Monjok Kecamatan Seleparang Kota Mataram Nusa Tenggara Barat. Society Journal, Vol 6 No.1 hal 15-30.

Kamus Besar Bahasa Indonesia. (2016). Jakarta: Balai Pustaka.

Kotler, P. (2009). M anajemen Pemasaran. Jakarta: Erlangga.

Marinus, A . (2002). D asar-D asar Pemasaran. Jakarta: PT. Raja Grafindo Persada.

Mukhtar, S., \& Nurif, M. (2015). Peranan Packaging Dalam Meningkatkan Hasil Produksi Terhadap Konsumen. Sosial Humaniora, Vol .8 No.2.

Nastain, M. (2017). Branding dan Eksistensi Produk (Kajian Teoritik Konsep Branding dan Tantangan Eksistensi Produk). Channel, Vol 5 No.1 Hal 14-26.

Rufaidah, P. (2015). Branding Strategy Berbasis Ekonomi Kreatif : Triple H elix Vs. Quadruple Helix. Bandung: Universitas Padjadjaran .

Stephen, A. (2016). The Role of Digital and Social Media Marketing in Consumer Behavior. Current 0 pinion in Psychology, 10, 17-21.

Sunyoto, D. (2013). Dasar-Dasar Manajemen Pemasaran. Yogyakarta: CAPS.

Tjiptono, F. (2015). Trategi Pemasaran. Yogyakarta: A ndi.

\section{FUNDING}

Kegiatan ini merupakan bagian dari program Pengabdian Kepada Masyarakat yang di danai oleh Universitas Serang Raya tahun

\section{COMPETING INTEREST}

Tidak ada konflik kepentingan untuk diungkapkan.

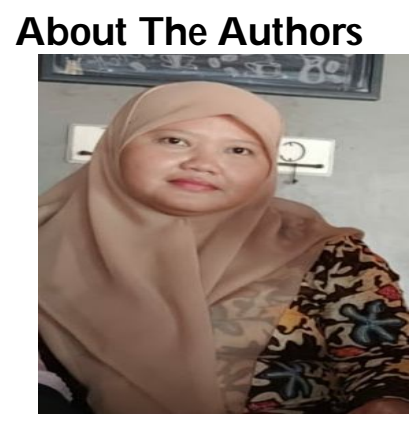

Dien Sefty, lahir pada tanggal 20 September 1984. Penulis merupakan Dosen Tetap Universitas Serang Raya pada Program Studi Akuntansi. Pengalaman mengajar penulis adalah dibidang akuntansi syariah, akuntansi biaya dan akuntansi manajemen. Email diensefty84@gmail.com

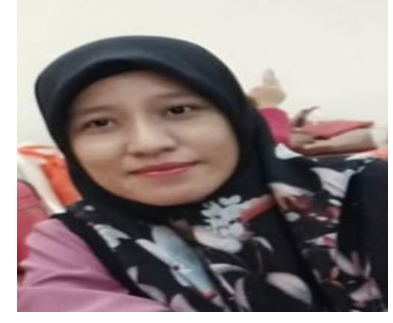

Dian Maulita, lahir pada tanggal 16 November 1987. Penulis merupakan Dosen Tetap Universitas Serang Rayapada Program Studi A kuntansi sejak tahun 2013. Email maulita.dian@gmail.com 